\title{
Low Temperature Tolerance of Apple Shoots Following Exposure to Warm Temperatures in Late Winter
}

\author{
Renae E. Moran \\ School of Food and Agriculture, University of Maine, PO Box 179, \\ Monmouth, ME 04259
}

Bryan J. Peterson

School of Food and Agriculture, University of Maine, Deering Hall, Orono, ME 04469

\section{Gennaro Fazio}

USDA-ARS Plant Genetic Resources Unit, Geneva, NY 14456

John A. Cline

Department of Plant Agriculture, Ontario Agricultural College, University of Guelph, Simcoe Research Station, Simcoe, ON N3Y 4N5, Canada

Additional index words. cambium, deacclimation, freeze injury, Malus $\times$ domestica, phloem, rootstock, winter hardiness, xylem

\begin{abstract}
The goal of this research was to evaluate resistance of apple rootstocks to late winter deacclimation during a 2-day exposure to warm temperatures in Maine. We measured the cold temperature tolerance of xylem, phloem, and cambium from 0 to $-40{ }^{\circ} \mathrm{C}$ in $1-$ and 2 -year-old shoot pieces from apple rootstock cultivars and advanced selections 'M.9 T337' (M.9), 'M.7 EMLA' (M.7), 'Budagovsky 9' (B.9), 'Geneva ${ }^{\circledR}$ 41' (G.41), 'Geneva 30' (G.30), 'Geneva 935' (G.935), 'Geneva 814' (G.814), G.4013, G.5257, and Vineland 6 (V.6) after a 2-day exposure to warm $\left(22^{\circ} \mathrm{C}\right)$ or cold $\left(2\right.$ to $\left.4{ }^{\circ} \mathrm{C}\right)$ temperatures. Injury was measured on a 0 to 10 rating scale based on percentage of discolored cross-sectional xylem and phloem, and cambial length and circumference with brown discoloration, with 0 indicating no browning and 10 indicating browning in the entire tissue. Injury was also measured as intensity of browning on a scale of 0 (no browning) to 5 (dark brown to black). The weighted averages of the two ratings were used to calculate an index of browning. Genotypic variation occurred in the degree of deacclimation, which ranged from none to as much as $15^{\circ} \mathrm{C}$ loss in hardiness. Two genotypes, 'G.41' and 'M.9', showed little change in hardiness in both years they were tested. Two genotypes, G.4013 and 'G.814', lost substantial hardiness in both years and may be vulnerable to late winter freeze-thaw events, but were among the hardiest before deacclimation. ' $G .935$ ' and G.5257 showed a small loss of hardiness, whereas 'B.9' lost hardiness in the cambium, but not the xylem, and V.6 lost hardiness after warm exposure, but showed almost no injury at temperatures as cold as $-35^{\circ} \mathrm{C}$. The loss of hardiness of these four genotypes that were tested in only one year should be verified with additional testing because of the potential for yearly variation.
\end{abstract}

Apple trees suffer from lethal and sublethal injury when severely cold temperatures occur following a warm spell or after trees have deacclimated (Howell and Weiser,

Received for publication 22 Dec. 2020. Accepted for publication $28 \mathrm{Feb} .2021$

Published online 11 May 2021

This project was supported by the USDA National Institute of Food and Agriculture Project NC140, through the Maine Agricultural \& Forest Experiment Station Hatch Project Number ME031912, and by The International Fruit Tree Association.

R.E.M. is the corresponding author. E-mail: rmoran@maine.edu.

This is an open access article distributed under the CC BY-NC-ND license (https://creativecommons. org/licenses/by-nc-nd/4.0/). among different genotypes (Layne, 1994; Layne et al., 1977; McArtney and Obermiller, 2011; Simons, 1970; Westwood and Bjornstad, 1981). However, in most cases, hardiness characterizations have been based on external trunk injury and tree survival, which may be confounded with infection by pathogens (Holubowicz et al., 1982), particularly in long-term studies (Barritt et al., 2004). Identifying and selecting genotypes with slow deacclimation in response to warming temperatures in late winter could potentially prevent injury and death of trees and limbs. Many promising apple rootstocks that possess good shoot hardiness in midwinter may lack the genetic capacity to adequately retain cold tolerance during temperature fluctuations in late winter and early spring (Caprio and Quamme, 1999).

Selection of adapted genotypes is an effective method of preventing cold temperature injury, and a large number of new genotypes are available from breeding programs in New York (Geneva series); Ontario, Canada (Vineland series); and Russia (Budagovsky series). Among the Malling rootstocks, 'M.9' had greater injury than 'M.7', 'M.26', and 'MM.106' from natural freeze events (Wildung et al., 1973). A field experiment performed in the Champlain Valley, NY, with 'Honeycrisp' and 'McIntosh' as the scions showed that 'M.7' and 'MM.106' had very poor survival $(<30 \%)$ following a midwinter cold event in 2004 (Robinson et al., 2006). In the same study, trees on 'O.3', 'V.1', 'V.3', 'G.16', 'G.30', and 'Mark' displayed the highest survival $(>90 \%)$, whereas trees on 'B.118', 'M.9 T337', 'B.9', 'M.9 Nic 29', 'Supporter 4', 'M.26', and 'MM.111' had only 50\% survival. These midwinter mortality events usually follow a warm period when the tree may have partially de-hardened. A trait of 'M.7' rootstock that might be contributing to its tenderness is that it was found to reduce the endodormancy (chilling) requirement of grafted scions, and by itself had a low endodormancy requirement (Couvillon et al., 1984; Young and Werner, 1984, 1985) suggesting that the mechanisms for endodormancy might overlap sensitivity to cold damage. These studies have shown cultivar variability in cold hardiness at a point in time in late winter, rather than the amount of hardiness that is lost when shoots are exposed to warm temperatures. In controlled deacclimation studies, cultivars of apple scions (Coleman, 1985), sweet and sour cherry (Mathers, 2004), peach (Shin et al., 2015), and hydrangea (Pagter et al., 2011) vary in the rate of deacclimation.

Naturally occurring freezes used to characterize rootstock cold hardiness are limited to genotypes in cultivation and can be confounded by other factors such as prior sublethal cold temperature injury and subsequent invasion by pathogens (Domoto, 1991; McArtney and Obermiller, 2011). Controlled freezing has shown 'M.9' to be less hardy in spring than 'M.7', 'M.26', and 'MM.106' (Wildung et al., 1973), and 'M.26' to be as hardy in late winter as 'Ottawa 3' and CG.10 
(Holubowicz et al., 1982), but most of these cultivars have become less important in production. Based on natural loss of hardiness in April, 'M.9' and 'G.214' are less likely to be vulnerable to injury in late winter than 'G.41', 'G.30', and 'G.814' (Moran et al., 2018). Additional research involving controlled deacclimation is needed to identify vulnerability among genotypes to cold temperature injury.

The objective of this research was to compare loss in cold temperature tolerance in select Geneva, Malling, and Vineland apple rootstocks following a 2-d exposure to warm temperatures in late winter.

\section{Materials and Methods}

Plant materials. Ungrafted liners of 1year-old apple rootstocks were planted in the field at a spacing of $15 \mathrm{~cm}$ and mulched with black plastic. The planting was located at the Maine Agricultural and Forest Experiment Station in Monmouth, ME (GPS coordinates 40.7129822, - 74.007205). The soil was a Dixfield fine sandy loam, course-loamy, mixed frigid typic Haplothords. The plastic mulch degraded after 3 years and was replaced by nursery groundcover (994GC; Lumite, Alto, GA). One-year-old apple rootstocks were planted in the field in 2011 (Geneva rootstocks 'G.935', G.4013, 'G.814', and G.5257), 2012 ('M.9', 'M.7', and Vineland selection V.6), and 2013 ('B.9' and 'G.41'). Thirty liners of each genotype were planted. Trees were not irrigated or fertilized during the duration of the study and received no crop protectant chemicals because of the lack of disease and pest problems.

Cold hardiness of genotypes was measured across 3 years in 2014, 2015, and 2017. Cultivars were selected for their commercial importance, and advanced selections were included based on prior spring hardiness measurements. Genotypes measured in 2014 included 'M.7', 'G.814', G.4013 and G.5257, which were selected for their variability in spring hardiness and sufficient growth to provide enough shoots. In 2015, 'M.7', 'M.9', 'B.9', 'G.41', 'G.814', and G.4013 were measured, and in 2017, 'M.9', 'G.41', 'G.935', and V.6 were measured (Supplemental Table 1). For some genotypes, there was an insufficient number of shoots for testing in every year.

Determination of cold hardiness. In each year, 14 branches of each genotype were cut at the base of 2-year-old wood and at a point above the snow. Shoots were cut on 1 Apr. in 2014, 16 Mar. in 2015, and 21 Mar. in 2017. Shoots were recut under water and placed in buckets with water at tap-water temperature. For each genotype, seven branches were held for $2 \mathrm{~d}$ at a warm temperature in a laboratory and seven branches at a cold temperature in a walk-in cold room. The warm temperature was $22 / 18^{\circ} \mathrm{C}$ day/night and the cold temperature was $2^{\circ} \mathrm{C}$ in 2014 and 2015 , and $4{ }^{\circ} \mathrm{C}$ in 2017. An additional seven branches of each genotype were also collected and held for $2 \mathrm{~d}$ at $10^{\circ} \mathrm{C}$ in 2017 to evaluate responses

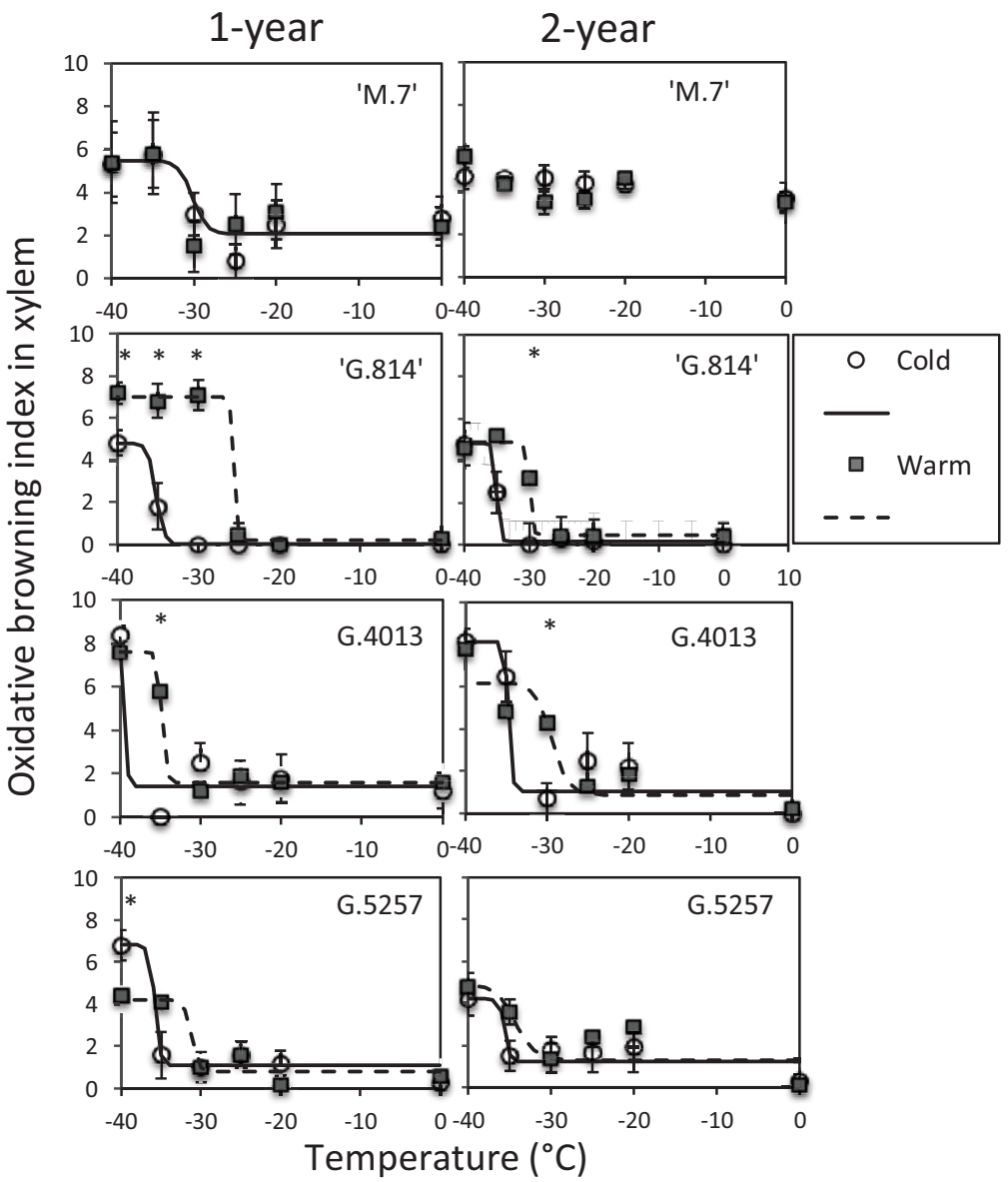

Fig. 1. Xylem browning in 1- and 2-year-old shoot sections exposed to subfreezing temperatures following $2 \mathrm{~d}$ of warm $\left(22^{\circ} \mathrm{C}\right)$ or cold $\left(2{ }^{\circ} \mathrm{C}\right)$ temperature in Apr. $2014 . \mathrm{y}=\mathrm{Bmax} /\left[1+\mathrm{e}^{\mathrm{b}(\mathrm{TI}-\mathrm{x})}\right]$, where $\mathrm{y}=$ browning index from none $(0)$ to severe (10) and $\mathrm{x}=$ temperature. Asterisks indicate a significant difference between warm- and cold-exposed shoots within a genotype and temperature.

following exposure to an intermediate (cool) temperature.

Following $2 \mathrm{~d}$ at treatment temperatures, whole shoots were transported to the laboratory at ambient temperatures for controlled freezing tests. One- and 2-year-old shoots were cut into 6- to $8-\mathrm{cm}$ pieces, which were wrapped with moist paper towels and placed in unsealed plastic bags. The transport and cutting process took $4 \mathrm{~h}$. The shoots in plastic bags were either left at $22^{\circ} \mathrm{C}$ (ambient-temperature controls) or placed in a temperaturecontrolled programmable freezer (SuperCold Freezer; Scientemp, Adrien, MI). In 2014, shoots were held at a temperature of $-4{ }^{\circ} \mathrm{C}$ for $1 \mathrm{~h},-8^{\circ} \mathrm{C}$ for $1 \mathrm{~h}$, and $-11^{\circ} \mathrm{C}$ for $12 \mathrm{~h}$. In 2015 and 2017 , shoots were held at $-5^{\circ} \mathrm{C}$ for $12 \mathrm{~h}$, after which the temperature at the shoot surface was decreased to $-40^{\circ} \mathrm{C}$ at a rate of $5^{\circ} \mathrm{C}$ per hour. Copper-constantan (Type $\mathrm{T}$ ) thermocouples were inserted between the bundled shoot pieces to measure shoot temperature. When thermocouples indicated that shoots had been at $-20,-25,-30$, -35 , and $-40^{\circ} \mathrm{C}$ for $1 \mathrm{~h}$, tissue samples were removed and transferred to an insulated cooler for $24 \mathrm{~h}$ during transport to a cold room where they were allowed to slowly thaw at $4{ }^{\circ} \mathrm{C}$. Before measurement, shoots were held at ambient temperature $\left(20^{\circ} \mathrm{C}\right)$ for $2 \mathrm{~d}$ to allow oxidative browning, and then placed back in cold storage at 2 to $4{ }^{\circ} \mathrm{C}$ until analysis of browning within 1 to 2 weeks.

Tissue browning was visually rated using a scale from 0 to 10 , where 0 indicated no browning and 10 indicated $100 \%$ of the xylem tissue area in cross section, cut just before observing, was discolored. To assess browning of phloem and cambium, shoots were cut lengthwise to the depth of the outer xylem. Phloem browning was measured as the relative depth and length of phloem tissue that was discolored. Cambial browning was measured as the relative length and circumference of cambium that was discolored. In addition, tissues were rated according to intensity of browning using a scale of 0 to 5 , where 0 indicated no browning and 5 indicated dark browning to blackening of the tissues. Both ratings were used to calculate an index of injury, which was the average of the two ratings according to the formula [area of discoloration + (intensity of discoloration $x$ 2)]/2 (Supplemental Fig. 1). Reading glasses with +3.00 strength and light-emitting diode lighting were used to improve visual observation of tissue browning.

Data analysis. Data were analyzed using SAS Version 9.4 (SAS Institute, Cary, NC) PROC NLIN and the Newton method to estimate the four parameters of an adjusted logistic sigmoid function, $\mathrm{y}=\mathrm{Bmax} /\left[1+\mathrm{e}^{\mathrm{b}(\mathrm{TI}-\mathrm{x})}\right]+\mathrm{d}$, 
where $y$ is the browning index, Bmax the maximum injury or upper asymptote, $b$ the slope at the inflection point, TI the temperature of injury which corresponds with the inflection point, $\mathrm{x}$ the temperature, and $\mathrm{d}$ the lower asymptote or injury that occurred before testing (Repo and Lappi, 1989). When no prior injury occurred $(d=0)$, parameter $d$ was dropped from the model. Genotypic differences were evaluated based on TI and their $90 \%$ confidence intervals determined using PROC NLIN. Significant browning differences among treatments but within a genotype and freezing temperature were based on means separation using the GLM LSMeans procedure, at the $5 \%$ level of significance.

\section{Results}

Xylem. In 2014, injury occurred before April in 'M.7', G.4013, and G.5257 xylem, but not in 'G.814' (Fig. 1). This occurred in both 1- and 2-year-old shoots. In 'M.7', warm-exposed shoots did not change hardiness compared with those exposed to cold. Warm-exposed shoots of 'G.814' and G.4013 had a greater browning index than cold-exposed shoots, and the loss of hardiness was substantial in 1-year-old shoots of 'G.814'. In 1-year-old shoots of G.5257, injury was greater at $-40^{\circ} \mathrm{C}$ in cold-exposed shoots compared with warm-exposed shoots at this same temperature, but injury was similar at other temperatures and in 2-year-old xylem. Due to the wide variation in xylem browning index in the injurious temperature range, genotypic and treatment differences in TI were not significant in 2014 and 2015 (not shown).

In 2015 , no prior injury occurred in 1year-old xylem, but mild to moderate browning occurred in 2-year-old shoots in all but G.4013 (Fig. 2). Warm-exposed 1-year-old shoots showed an increase in browning index compared with cold-exposed shoots in 'M.7', 'M.9', and 'G.814'. Loss of hardiness following warm exposure was dramatic in 'G.814', which had no injury in cold-exposed shoots at temperatures as cold as $-40^{\circ} \mathrm{C}$. In 2-yearold shoots, warm exposure caused loss of hardiness in 'G.814' and G.4013, but no change in hardiness occurred in 'M.7', 'M.9', 'B.9', and 'G.41'.

In 2017, 'M.9' and V.6 lost hardiness after exposure to warm $\left(22 / 18^{\circ} \mathrm{C}\right.$ day/night $)$ or cool $\left(10^{\circ} \mathrm{C}\right)$ conditions, compared with shoots exposed only to cold $\left(4^{\circ} \mathrm{C}\right)$, and warm-exposed shoots were less hardy than shoots exposed to cool temperatures (Table 1; Fig. 3). Only 2-year-old shoots were measured in 2017. V.6 had almost no xylem injury at temperatures as cold as $-35^{\circ} \mathrm{C}$, but severe injury at $-38^{\circ} \mathrm{C}$ in cool- and warmexposed shoots, in contrast to none in coldexposed shoots. Exposure of ' $\mathrm{G} .41$ ' and 'G.935' shoots to warm conditions did not cause loss of hardiness relative to the control, and only partial injury of the xylem occurred at temperatures below $-30{ }^{\circ} \mathrm{C}$.

Cambium. In 2014, moderate to severe browning occurred in cambial tissues at temperatures below -25 to $-35^{\circ} \mathrm{C}$ (Fig. 4). Warm

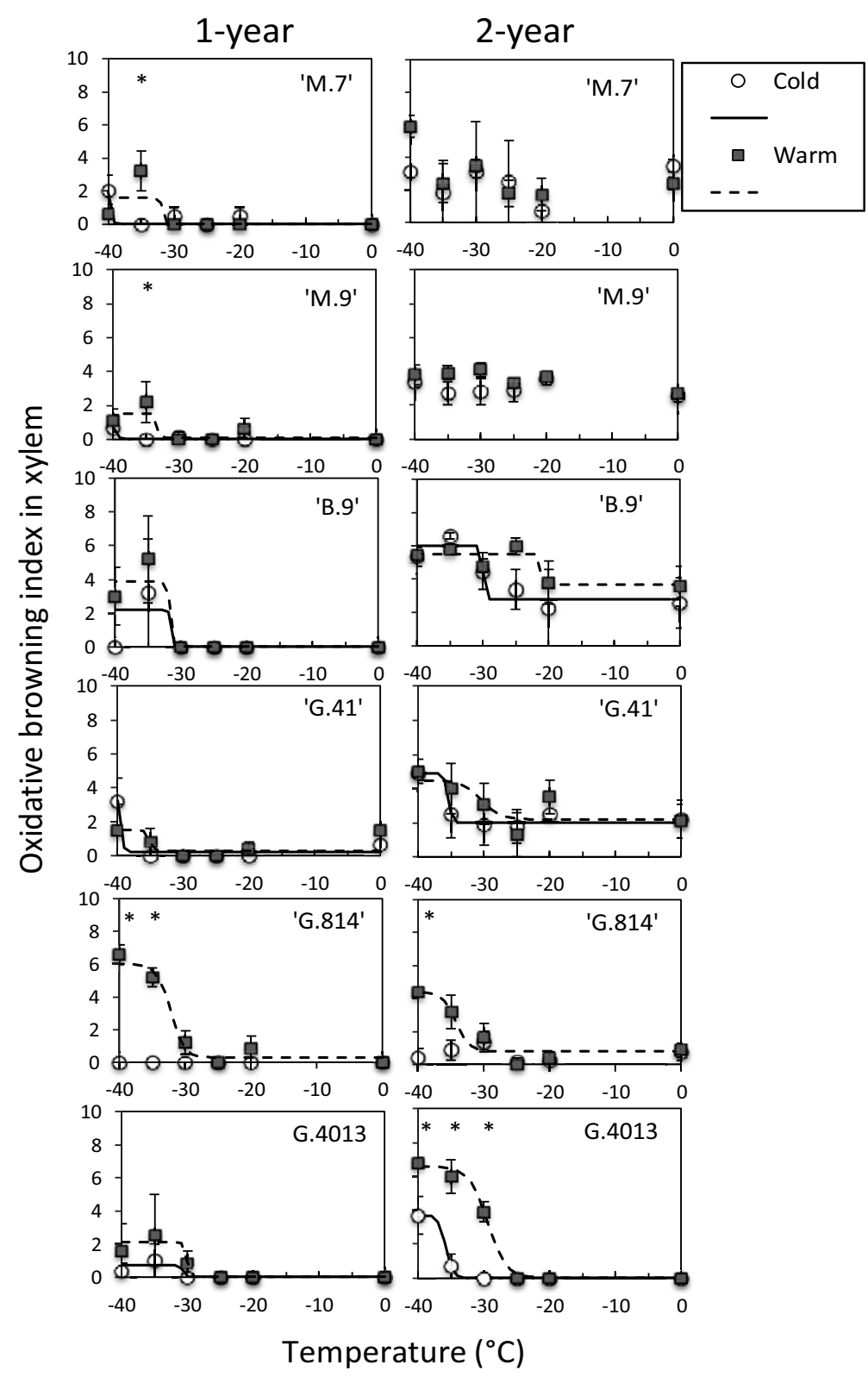

Fig. 2. Xylem browning in 1- and 2-year-old shoot pieces exposed to subfreezing temperatures following $2 \mathrm{~d}$ of warm $\left(22^{\circ} \mathrm{C}\right)$ or cold $\left(2{ }^{\circ} \mathrm{C}\right)$ temperature in Mar. $2015 . \mathrm{y}=\mathrm{Bmax} /\left[1+\mathrm{e}^{\mathrm{b}(\mathrm{TI}-\mathrm{x})}\right]$, where $\mathrm{y}=$ browning index from none $(0)$ to severe (10) and $\mathrm{x}=$ temperature. Asterisks indicate a significant difference between warm- and cold-exposed shoots within a genotype and temperature.

exposure caused loss of hardiness relative to cold exposure in 1-year-old shoots of 'G.814', G.4013, and G.5257, and in 2-year-old shoots of all genotypes. This was most dramatic in 2year-old shoots of G.4013, which had a TI of $-40^{\circ} \mathrm{C}$ in cold-exposed shoots compared with $-25^{\circ} \mathrm{C}$ in warm-exposed shoots (Table 2). Based on TI, no genotypic differences occurred in cold-exposed 1-year-old shoots, but in 2year-old shoots, cambium of 'G.814' was less hardy than in 'M.7' and G.4013. In warm-exposed 1-year-old shoots, cambium TI was warmer in 'G.814' than in 'M.7' and G.4013, and in 2-year-old warm-exposed shoots, cambium TI was warmer in 'M.7' than in other genotypes. Overall, 'M.7' cambium was least hardy, and G.5257 was most hardy.

In 2015, warm exposure caused a loss of hardiness in cambial tissue in 1-year-old shoots of 'G.814' and G.4013, and in 2-yearold shoots of 'M.7', 'B.9', 'G.814', and G.4013 (Fig. 5). Genotypic differences in TI did not occur in cold-exposed shoots (Table 2). In warm-exposed 1-year-old shoots, cambial injury occurred at a warmer temperature in G.4013 than in 'G.814' and 'G.41'. In cold-exposed 2-year-old shoots, cambial browning index was partial $(<6)$ in most genotypes, so comparison of the TI was not meaningful (e.g., 'M.9' had the warmest TI, but only slight injury). In 2-year-old warmexposed shoots, the TI was warmer in 'G.814', G.4013, and 'M.9' than in other genotypes, but in 'M.9', browning index was low.

In 2017, the cambium in 'M.9' and 'G.41' remained as hardy in warm- and coolexposed shoots as in cold-exposed shoots 


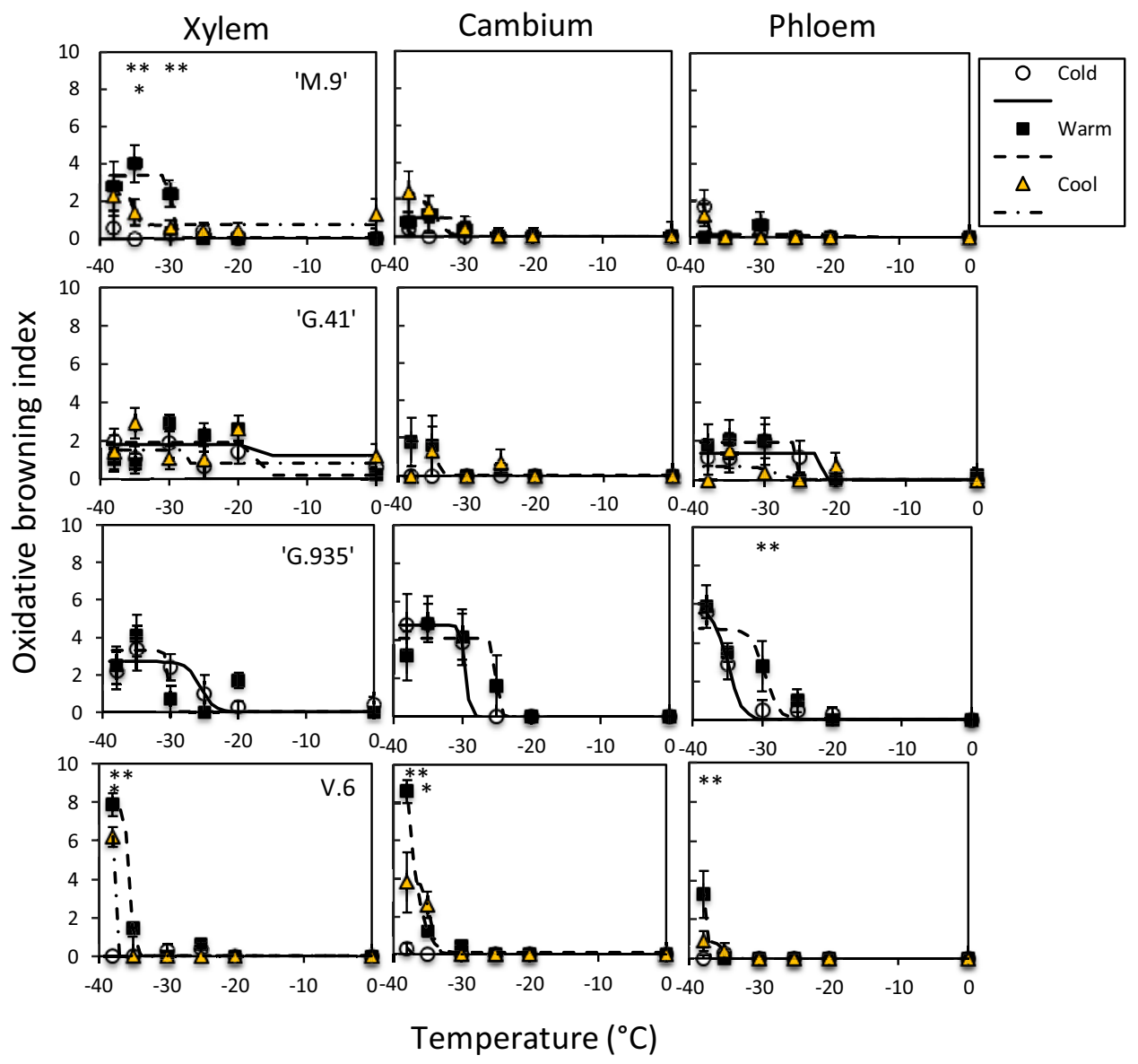

Fig. 3. Xylem, cambial, and phloem browning in 2-year-old shoot pieces exposed to subfreezing temperatures following $2 \mathrm{~d}$ of warm $\left(22^{\circ} \mathrm{C}\right)$, cool $\left(10{ }^{\circ} \mathrm{C}\right)$, or cold $\left(4{ }^{\circ} \mathrm{C}\right)$ temperature in Mar. 2017. $y=\mathrm{Bmax} /\left[1+\mathrm{e}^{\mathrm{b}(\mathrm{TI}-\mathrm{x})}\right]$, where $\mathrm{y}=$ browning index from none $(0)$ to severe $(10)$ and $\mathrm{x}=$ temperature. Asterisks indicate a significant difference between warm-, cool-, and cold-exposed shoots within a genotype and temperature.

(Table 1; Fig. 3). In cold-exposed shoots, almost no injury occurred in 'M.9', 'G.41', and V.6 at $-38^{\circ} \mathrm{C}$, but 'G.935' had a moderate browning index at temperatures below $-25^{\circ}$ C. In 'G.935', for which we had only cold- and warm-exposed shoots, no differences in hardiness were evident between the two treatments. In V.6, cool- and warm-exposed shoots lost hardiness compared with cold-exposed shoots, with greater loss following warm exposure.

Phloem. In 2014, phloem browning index at $-40{ }^{\circ} \mathrm{C}$ was low in all genotypes and only slightly greater in warm-exposed shoots of both ages (data not shown). The browning index was 4 or less, indicating that injury was partial and that part of the phloem was hardy to $-40^{\circ} \mathrm{C}$. In 2017 , and in shoots of both ages, phloem browning index was unchanged in warm-exposed shoots of 'M.7', 'M.9', 'G.41', and 'G.814' (Fig. 6). One-year-old shoots of 'B.9' also showed no change in hardiness, but 2-year-old shoots had a large loss in phloem hardiness after warm exposure. Warm exposure also caused a loss of hardiness in 1-year-old shoots of G.4013. In 2017, when only 2 -year-old shoots were measured, 'M.9' and 'G.41' showed a similar response as in 2015. 'G.935' and V.6 lost phloem hardiness after warm exposure. Exposure of shoots to cool conditions $\left(10^{\circ} \mathrm{C}\right)$ did not cause a loss of phloem hardiness in any genotype.

\section{Discussion}

Genotypic variation occurred in the degree of deacclimation, which ranged from none to as much as $15^{\circ} \mathrm{C}$ (based on TI). Two genotypes, 'G.41' and 'M.9', showed little change in hardiness in both years they were tested, and 'G.935' in the one year it was tested. Two genotypes, G.4013 and 'G.814', lost substantial hardiness in both years and may be vulnerable to late winter freeze-thaw events. A moderate loss of hardiness occurred in 'B.9', G.5257, and V.6, but this loss was limited to the cambium in G.5257 and to the cambium and phloem in 'B.9', but additional testing is needed beyond 1 year to confirm the degree of deacclimation in these genotypes. These results differed somewhat from deacclimation characterized under natural conditions in the same trees of G.5257, which were less hardy in xylem and cambium than in most other genotypes (Moran et al., 2018), and in 'B.9', which had relatively high latewinterhardiness under natural conditions in April, but only intermediate hardiness following controlled deacclimation. The cambium of G.4013 was among the most responsive to warm temperatures in this study, but showed a greater degree of hardiness in natural deacclimation conditions compared with G.5257. Natural loss of cambium and xylem hardiness from January to April in ' $G .814$ ' was greater than in most other genotypes, but was less responsive to deacclimating temperatures in this study. Deacclimation in this study was of a short duration and may not be comparable to the cumulative effect of warm temperatures over a longer period. More than $5 \mathrm{~d}$ of warm temperatures may be needed to cause a measurable deacclimation in some genotypes, as previously reported for hydrangea shoots (Pagter et al., 2011). Additional research is needed to confirm this for apple cultivars.

Following a natural, severe freeze-thaw cycle in North Carolina, 'Golden Delicious' external trunk injury was severe in 'M.9', intermediate 'G.935' and 'G.41', and lowest in 'B.9', but 'B.9' had poor subsequent survival (McArtney and Obermiller, 2011). Our results varied from these, but were based on internal injury rather than external symptoms (Supplemental Figs. 2 and 3). Conditions in the natural environment are more variable and complex than those in this study, a factor to consider when translating the results of this study to orchard conditions.

The cool treatment $\left(10^{\circ} \mathrm{C}\right)$ tested in 2017 resembles daily maximum temperatures that commonly occur in Maine during early spring, whereas the warm treatment 


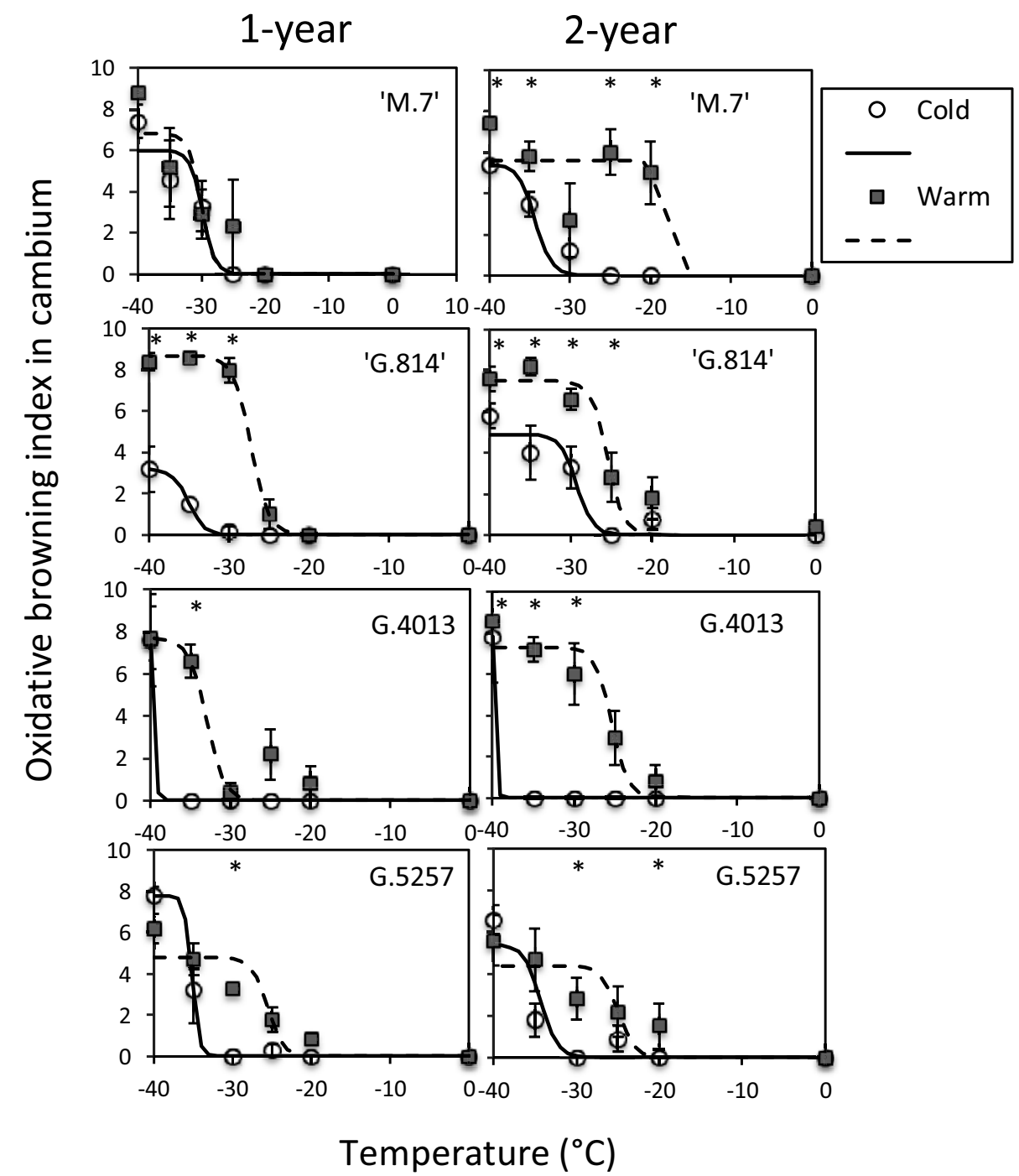

Fig. 4. Cambial browning in 1- and 2-year-old shoot pieces exposed to subfreezing temperatures following $2 \mathrm{~d}$ of warm $\left(22^{\circ} \mathrm{C}\right)$ or cold $\left(2{ }^{\circ} \mathrm{C}\right)$ temperature in Apr. 2014. $y=\operatorname{Bmax} /\left[1+\mathrm{e}^{\mathrm{b}(\mathrm{TI}-\mathrm{x})}\right]$, where $\mathrm{y}=$ browning index from none $(0)$ to severe $(10)$ and $\mathrm{x}=$ temperature. Asterisks indicate a significant difference between warm- and cold-exposed shoots within a genotype and temperature.

Table 1. Temperature of injury (TI) in xylem and cambial tissue in 2-year-old shoots of four apple rootstock genotypes exposed to 2 $\mathrm{d}$ of $22^{\circ} \mathrm{C}$ (warm), $10^{\circ} \mathrm{C}$ (cool), or $4{ }^{\circ} \mathrm{C}$ (cold control) in Mar. 2017. The TI value is estimated as the inflection point from nonlinear regression of oxidative browning index vs. temperature.

\begin{tabular}{llcrr}
\hline Genotype Treatment & \multicolumn{2}{c}{ Xylem } & \multicolumn{2}{c}{ Cambium } \\
\hline 'M.9' & Control & $<-40.0 \mathrm{a}^{\mathrm{z}}$ & $<-40.0$ & -34.4 \\
& Cool & $-34.6 \mathrm{~b}$ & -34.4 & -39.2 \\
& Warm & $-29.8 \mathrm{c}$ & -30.1 & $<-40.0$ \\
'G.41' & Control & ne & $<-40.0$ & $<-40.0$ \\
& Cool & ne & $<-40.0$ & $<-40.0$ \\
& Warm & ne & -34.5 & -25.7 \\
'G.935' & Control & -26.2 & -29.5 & -35.0 \\
& Warm & -30.3 & -25.1 & -29.9 \\
V.6 & Control & $<-40.0$ & $<-40.0$ & $>-40.0$ \\
& Cool & -40.0 & -34.9 & -40.0 \\
& Warm & -35.4 & -36.9 & -37.4 \\
& & & NS & NS \\
\hline
\end{tabular}

${ }^{\mathrm{z}}$ Means separation within a column and genotype is by $90 \%$ confidence interval. Means within a column followed by the same letter are not significantly different. ne $=$ not estimable; $\mathrm{Ns}=$ not significant.
Table 2. Temperature of injury (TI) in cambial shoot tissue in seven apple rootstock genotypes exposed to $2 \mathrm{~d}$ of $22^{\circ} \mathrm{C}$ (warm) or $2^{\circ} \mathrm{C}$ (cold control) in Apr. 2014 and 2015. The TI value is estimated as the inflection point from nonlinear regression of oxidative browning vs. temperature.

\begin{tabular}{|c|c|c|c|c|c|}
\hline \multirow[b]{2}{*}{ Treatment } & \multirow[b]{2}{*}{ Genotype } & \multicolumn{2}{|c|}{2014} & \multicolumn{2}{|c|}{2015} \\
\hline & & $1-y r$ & $2-y r$ & $1-y r$ & $2-\mathrm{yr}$ \\
\hline \multirow[t]{7}{*}{$\overline{\text { Control }}$} & 'M.7' & $-29.8 \mathrm{a}^{\mathrm{*}^{\mathrm{z}}}$ & $-34.0 \mathrm{a}$ & $-30.2 \mathrm{abc}$ & $-29.8 \mathrm{abc}$ \\
\hline & 'G.814' & $-35.1 \mathrm{a}^{*}$ & $-29.3 b$ & $<-40.0 \mathrm{a}^{*}$ & $-29.3 \mathrm{~b}$ \\
\hline & G.4013 & $-38.4 \mathrm{a}$ & $-39.7 \mathrm{a}$ & $-40.0 \mathrm{a}$ & $-37.2 a b c$ \\
\hline & G.5257 & $-35.2 \mathrm{a}$ & $-35.3 a b$ & - & - \\
\hline & 'M.9’ & - & - & $-32.7 a b c$ & $-25.0 a b c$ \\
\hline & 'B.9' & - & - & $-39.0 a b c$ & $-35.2 a b c$ \\
\hline & 'G.41' & - & - & $-35.2 a b c$ & $<-40.0 \mathrm{a}$ \\
\hline \multirow[t]{7}{*}{ Warm } & 'M.7' & $-30.3 \mathrm{a}^{*}$ & $-19.6 \mathrm{~d}$ & $-25.7 \mathrm{bc}$ & $-24.3 \mathrm{c}$ \\
\hline & 'G.814' & $-27.3 b^{*}$ & $-25.5 \mathrm{c}$ & $-31.2 b$ & $-29.1 \mathrm{~b}$ \\
\hline & G.4013 & $-33.0 \mathrm{a}^{*}$ & $-25.4 \mathrm{c}$ & $-26.8 c^{*}$ & $-31.0 \mathrm{~b}$ \\
\hline & G.5257 & $-28.4 a b$ & $-29.9 \mathrm{~b}$ & - & - \\
\hline & 'M.9' & - & - & $-24.6 b c$ & $-29.0 \mathrm{~b}$ \\
\hline & 'B.9' & - & - & $-31.8 a b c$ & $-24.8 \mathrm{c}$ \\
\hline & 'G.41' & - & - & $-31.7 a b$ & $-25.3 \mathrm{c}$ \\
\hline
\end{tabular}

${ }^{\mathrm{z}}$ Means separation within a column is by $90 \%$ confidence interval. Means within a column followed by the same letter indicate no significant differences.

*Indicates significant difference between shoot ages within a genotype.

resembles the infrequent warm conditions did not cause a loss in hardiness in 2017. It is that can occur during the same period (Moran not clear if there is a threshold temperature or et al., 2018). Two days of cool temperature duration for deacclimation in apple, and the 


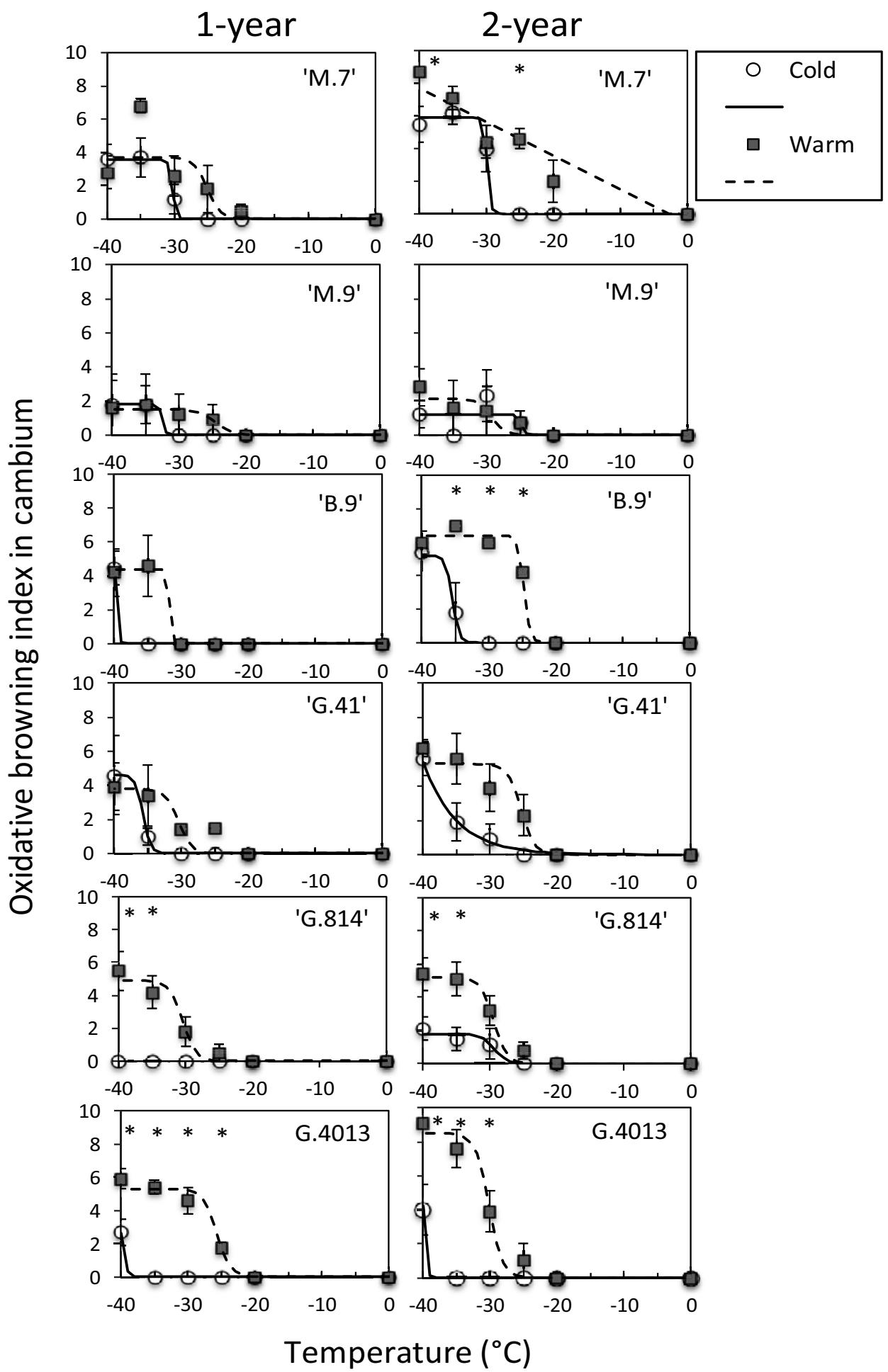

Fig. 5. Cambial browning in 1- and 2-year-old shoot pieces exposed to subfreezing temperatures following $2 \mathrm{~d}$ of warm $\left(22^{\circ} \mathrm{C}\right)$ or cold $\left(2{ }^{\circ} \mathrm{C}\right)$ temperature in Mar. 2015. $y=B \max /\left[1+\mathrm{e}^{\mathrm{b}(\mathrm{TI}-\mathrm{x})}\right]$, where $\mathrm{y}=$ browning index from none $(0)$ to severe $(10)$ and $\mathrm{x}=$ temperature. Asterisks indicate a significant difference between warm- and cold-exposed shoots within a genotype and temperature.

rate of deacclimation in apple compared with other temperate tree species has not been characterized. In Vitis vinifera, $10^{\circ} \mathrm{C}$ causes deacclimation after $4 \mathrm{~d}$ in fully chilled buds, but a longer duration is required to deacclimate buds that have received fewer chilling hours (Kovaleski et al., 2018). In Japanese white birch, deacclimation in the xylem occurred at $-3{ }^{\circ} \mathrm{C}$, but more than $3 \mathrm{~d}$ was needed for a measurable response, and warmer temperatures were needed for phloem deacclimation (Takeuchi and Kasuga, 2018). In addition to deacclimation temperature, the physiological history of the plant (the state of endodormancy) can also play a role in deacclimation rate and severity (Kalberer et al., 2007)

The amount of deacclimation varied among the three shoot tissues. At the time of testing, the cambium showed a high degree of hardiness within the control treatment, with little injury at temperatures as cold as $-35^{\circ} \mathrm{C}$ in G.4013, 'M.9', 'B.9', 'G.41', and V.6. A 2-d exposure to warm temperature was sufficient to cause loss of cambial hardiness in most genotypes, but not of the phloem. Deacclimation in the xylem occurred, but was not as severe as in the cambium in 2014 and 2015. In sweet cherry (Prunus avium), phloem deacclimates more rapidly than 


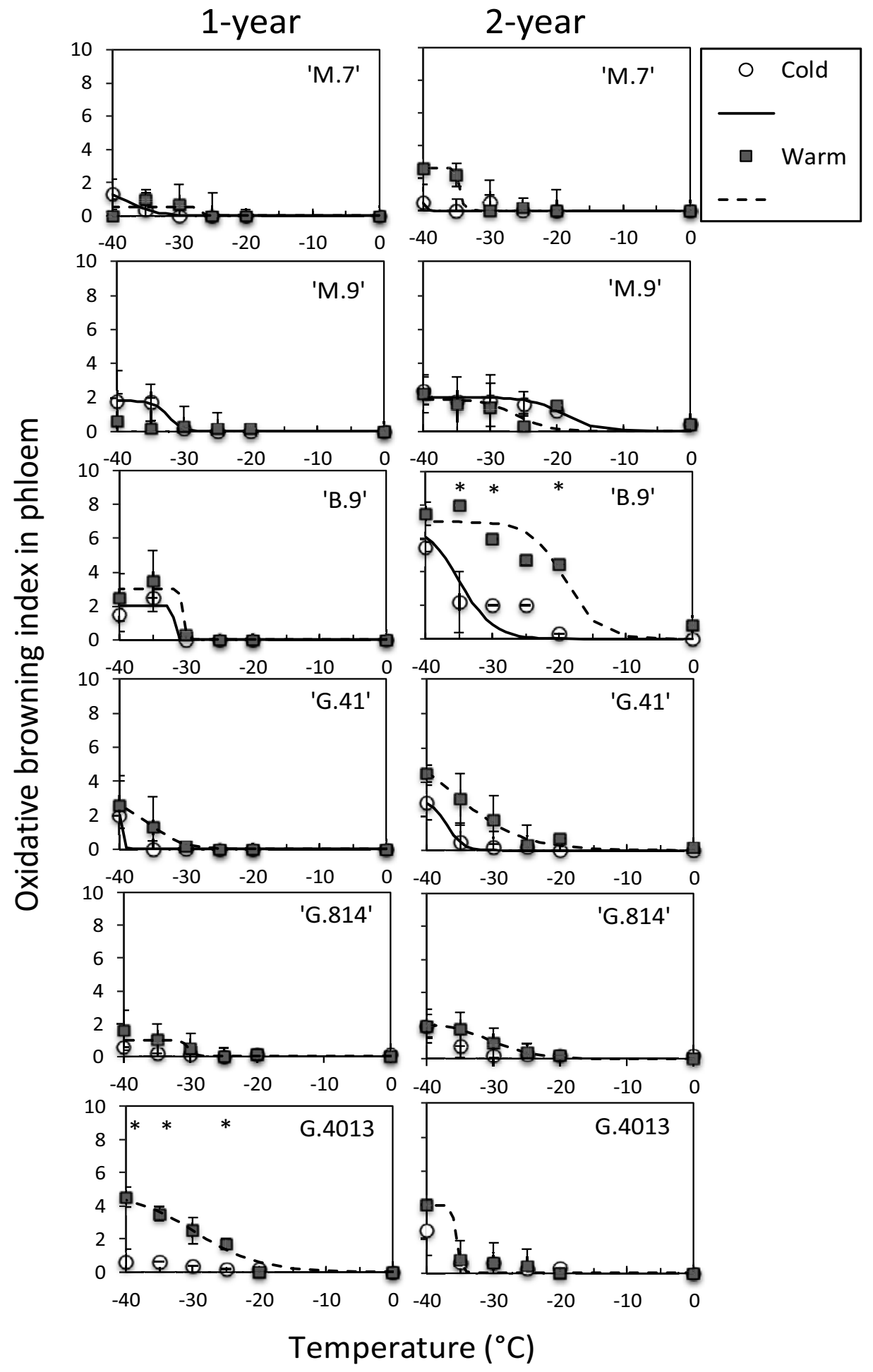

Fig. 6. Phloem browning in 1- and 2-year-old shoot pieces exposed to subfreezing temperatures following $2 \mathrm{~d}$ of warm $\left(22^{\circ} \mathrm{C}\right)$ or cold $\left(2{ }^{\circ} \mathrm{C}\right)$ temperature in Mar. 2015. $y=B m a x /\left[1+e^{b(T I-x)}\right]$, where $y=$ browning index from none $(0)$ to severe $(10)$ and $x=$ temperature. Asterisks indicate a significant difference between warm- and cold-exposed shoots within a genotype and temperature.

xylem under natural conditions in late winter, whereas the difference in deacclimation between tissues is smaller in sour cherry (Prunus cerasus; Mathers, 2004), and 'Golden Delicious' (Ketchie, 1985) and 'Haralson' apples (Quamme et al., 1972). However, in quince, the three shoot tissues are similar in hardiness in late winter (Einhorn et al.,
2011). Under controlled conditions, birch phloem deacclimates more slowly than xylem (Takeuchi and Kasuga, 2018), a dynamic that is similar to most of the genotypes in our study, where the phloem was slower to deacclimate than the xylem and cambium.

In apple rootstock cultivars, surficial root primordia, visible as a swelling at the nodes, are less hardy than other parts of the shoot in spring (Holubowicz et al., 1982). We observed a similar phenomenon in our study, but did not systematically measure it. Injury of the nodal section beneath the leaf bud occurred at warmer temperatures than injury of the internodal sections and shoot tissues on opposite sides of the leaf bud. It is not clear 
how this sensitivity contributes to tree mortality.

Older branches are generally less hardy than younger shoots (Quamme and Hampson, 2004). In our study, the cambium from 2-yearold shoots was generally hardier than cambium of 1-year-old shoots in 2014, but not in 2015 . This shoot age effect also did not consistently occur in xylem or phloem. The phloem in 2year-old shoots showed greater deacclimation than phloem in 1-year-old shoots of 'B.9' and 'G.41', but the opposite occurred in G.4013, indicating an interaction of shoot age and genotype with an unknown cause.

We did not measure the ability of shoots to regain hardiness, but this could be an important trait that may be cultivar dependent. The ability to reacclimate has been measured in peach (Shin et al., 2015) and sour cherry (Mathers, 2004), but research on apple shoots is lacking.

In conclusion, G.4013 and 'G.814' showed greater deacclimation during warm temperatures in late winter than 'M.9' and 'G.41', but a high degree of hardiness when acclimated. 'G.935' and G.5257 showed a small loss of hardiness in the 1 year they were tested. 'B.9' lost hardiness in the cambium, but not the xylem. V.6 lost hardiness after warm exposure, but showed almost no injury at temperatures as cold as $-35^{\circ} \mathrm{C}$. The loss of hardiness of these four genotypes that were tested in only 1 year should be verified with additional testing due to the potential for yearly variation. These results may assist growers in selecting rootstocks that are better suited to climates with unseasonable warm winter temperatures.

\section{Literature Cited}

Barritt, B.H., B.S. Konishi, and M.A. Dilley. 2004. The influence of 12 clones and 12 other dwarfing rootstock on 'Fuji' apple tree growth, productivity and susceptibility to southwest trunk injury in Washington. Acta Hort. 658: 103109, doi: 10.17660/ActaHortic.2004.658.12.

Caprio, J.M. and H.A. Quamme. 1999. Weather conditions associated with apple production in the Okanagan Valley of British Columbia. Can. J. Plant Sci. 79(1):121-137, doi: 10.4141/P98-028.

Coleman, W.K. 1985. Variations in cold resistance among apple cultivars during deacclimation. J. Expt. Bot. 36(168):1159-1171, doi: 10.1093/ $\mathrm{jxb} / 36.7 .1159$.
Couvillon, G.A., N. Finardi, M. Magnani, and C. Freire. 1984. Rootstock influences the chilling requirement of 'Rome Beauty' apple in Brazil. HortScience 19:255-256.

Domoto, P.A. 1991. Low temperature tolerance of 'Starkspur Supreme Delicious' on nine rootstocks in the Iowa 1980-1981 cooperative planting. Fruit Var. J. 45(4):224-229. <https:// www.pubhort.org/aps/45/v45_n4_a7.htm $>$.

Einhorn, T.C., J. Turner, D. Gibeaut, and J.D. Postman. 2011. Characterization of cold hardiness in quince: Potential pear rootstock candidates for northern pear production regions. Acta Hort. 909:137-143, doi: 10.17660/ ActaHortic.2011.909.13.

Holubowicz, T., J.N. Cummins, and P.L. Forsline. 1982. Responses of Malus clones to programmed low-temperature stresses in late winter. J. Amer. Soc. Hort. Sci. 107:492-496.

Howell, G.S. and C.J. Weiser. 1970. Fluctuations in the cold resistance of apple twigs during spring dehardening. J. Amer. Soc. Hort. Sci. 95:190-192.

Kalberer, S.R., R. Arora, N. Leyva-Estrada, and S.L. Krebs. 2007. Cold hardiness of floral buds of deciduous azaleas: Dehardening, rehardening, and endodormancy in late winter. J. Amer. Soc. Hort. Sci. 132(1):73-79, doi: 10.21273/ JASHS.132.1.73.

Ketchie, D.O. 1985. Cold resistance of apple trees through the year and its relationship to the physiological stages. Acta Hort. 168:131-137, doi: 10.17660/ActaHortic.1985.168.13.

Kovaleski, A.P., B.I. Reisch, and J.P. Londo. 2018. Deacclimation kinetics as a quantitative phenotype for delineating the dormancy transition and thermal efficiency for budbreak in Vitis species. AoB Plants 10(5):ply066, doi: 10.1093/aobpla/ ply066.

Layne, R. 1994. Prunus rootstocks affect longterm orchard performance of 'Redhaven' peach on Brookston clay loam. HortScience 29:167171, doi: 10.21273/HORTSCI.29.3.167.

Layne, R., H.O. Jackson, and F.D. Stroud. 1977. Influence of peach seedling rootstocks on defoliation and cold hardiness of peach cultivars. J. Amer. Soc. Hort. Sci. 102:89-92.

Mathers, H.M. 2004. Supercooling and cold hardiness in sour cherry germplasm: Vegetative tissue J. Amer. Soc. Hort. Sci. 129:682-689, doi: 10 . 21273/JASHS.129.5.0682.

McArtney, S. and J.D. Obermiller. 2011. Effect of dwarfing rootstocks on low temperature tolerance of 'Golden Delicious' apple trees during winter 2008-2009. J. Amer. Soc. Pomol. Sci. 65(4):178-184. <https://www.pubhort.org/aps/ 65/v65_n4_a1.htm $>$.

Moran, R.E., B.J. Peterson, G. Fazio, and J. Cline. 2018. Genotypic variation in apple rootstock low temperature tolerance during spring and fall. J. Amer. Soc. Hort. Sci. 143(5):319-332, doi: 10.21273/JASHS04470-18.

Pagter, M., J. Hausman, and R. Arora. 2011. Deacclimation kinetics and carbohydrate changes in stem tissues of Hydrangea in response to an experimental warm spell. Plant Sci. 180(1):140 148, doi: 10.1016/j.plantsci.2010.07.009.

Quamme, H. and C. Hampson. 2004. Winter hardiness measurements on 15 new apple cultivars. J. Amer. Pomol. Soc. 58(2):98-107. < https:// www.pubhort.org/aps/58/v58_n2_a13.htm $>$.

Quamme, H., C. Stushnoff, and C.J. Weiser. 1972. The relationship of exotherms to cold injury in apple stem tissues. J. Amer. Soc. Hort. Sci. 97: 608-613.

Repo, T. and J. Lappi. 1989. Estimation of standard error of impedance-estimated frost resistance. Scand. J. For. Res. 4:67-74, doi: 10.1080/ 02827588909382547.

Robinson, T.L., G. Fazio, H.S. Aldwinckle, S.A. Hoying, and N. Russo. 2006. Field performance of Geneva apple rootstocks in the Eastern USA. Sodinink. Darzinink. 25:181-191.

Rochette, P., G. Belanger, Y. Castonguay, A. Bootsma, and D. Mongrain. 2004. Climate change and winter damage to fruit trees in eastern Canada. Can. J. Plant Sci. 84:1113-1125.

Shin, H., Y. Oh, and D. Kim. 2015. Differences in cold hardiness, carbohydrates, dehydrins and related gene expressions under an experimental deacclimation and reacclimation in Prunus persica. Physiol. Plant. 154(4):485-499.

Simons, R.K. 1970. Phloem tissue development in response to freeze injury to trunks of apple trees. J. Amer. Soc. Hort. Sci. 95:182-190.

Takeuchi, M. and J. Kasuga. 2018. Bark cells and xylem cells in Japanese white birch twigs initiate deacclimation at different temperatures. Cryobiology 80:96-100.

Westwood, M.N. and H.O. Bjornstad. 1981. Winter injury to apple cultivars as affected by growth regulators, weed control method, and rootstocks. J. Amer. Soc. Hort. Sci. 106:430-432

Wildung, D.K., C.J. Weiser, and H.M. Pellet. 1973. Cold hardiness of Malling clonal apple rootstocks under different conditions of winter soil cover. Can. J. Plant Sci. 53:323-329.

Young, E. and D.J. Werner. 1984. Effects of rootstock and scion chilling during rest on resumption of growth in apple and peach. J. Amer. Soc. Hort. Sci. 109:548-551.

Young, E. and D.J. Werner. 1985. Effects of shoot, root, and shank chilling during rest in apple and peach on growth resumption and carbohydrates. J. Amer. Soc. Hort. Sci. 110: 769-774. 
Supplemental Table 1. Summary of the factorial arrangement of the temperatures during the 2-day exposure period, shoot ages and genotypes measured each year of the study.

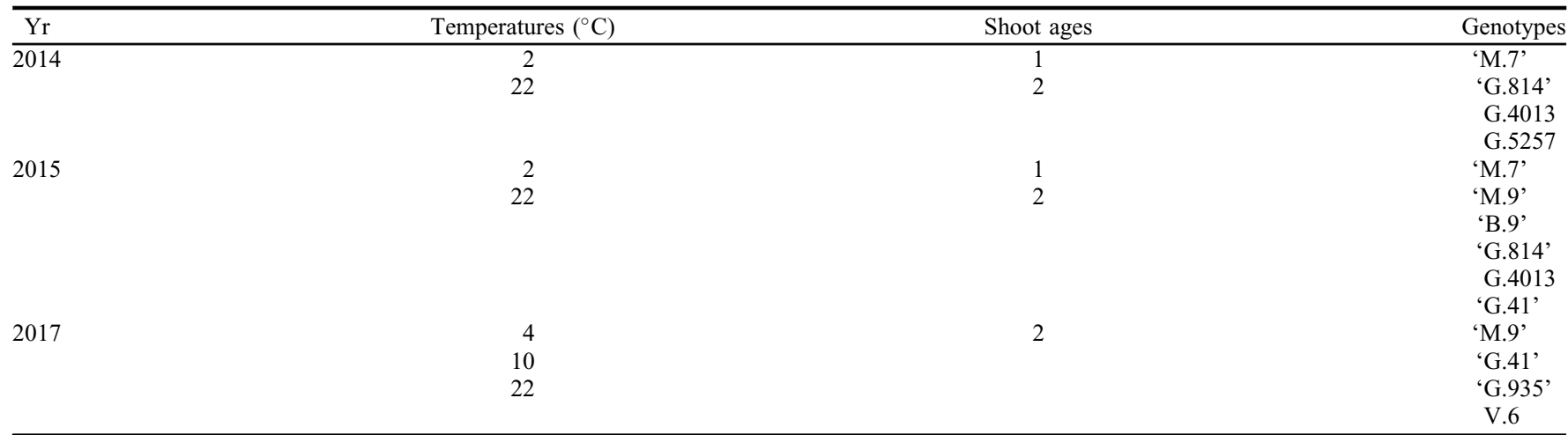
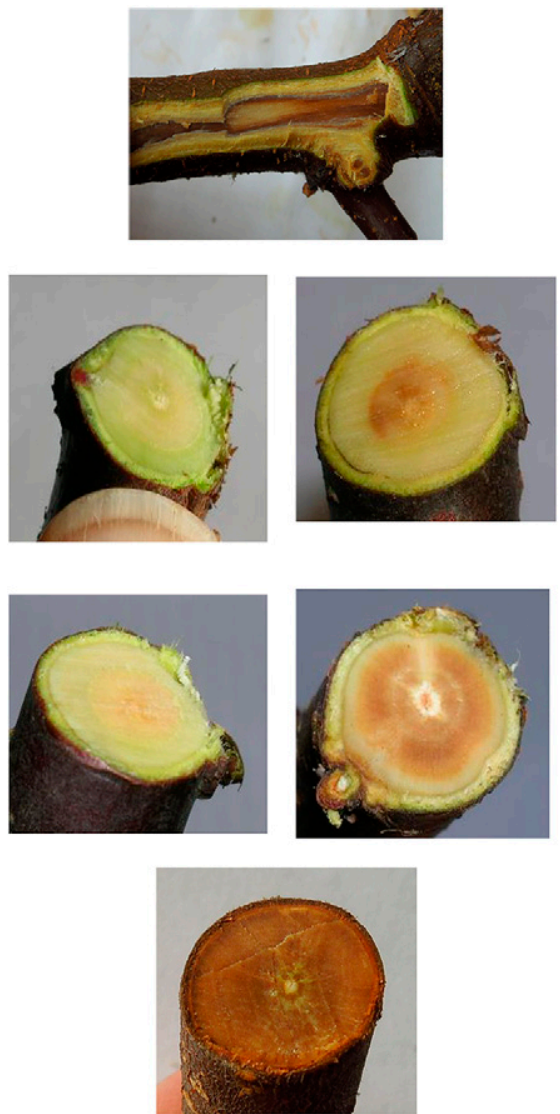

Supplemental Fig. 1. (A-F) Oxidative browning in the phloem, cambium, and xylem in shoot cross-sections and the corresponding index of browning for each tissue. (A) Phloem and cambial oxidative browning in a 2-year-old shoot section. Browning is present in 100\% of the cambial tissue, corresponding to a rating of 10 , and an intensity rating of 5 (very dark brown to black). Oxidative cambial browning index $=10.0$. In the phloem, browning is present in approximately $50 \%$ of the tissue, corresponding to a rating of 5, and an intensity rating of 2.5 (a mix of tan and brown). Oxidative phloem browning in$\mathrm{dex}=5.0$. (B) Two-year-old shoot section with no xylem browning. Oxidative browning index $=0.0$. (C) Two-year-old shoot section showing browning in approximately $30 \%$ of the xylem, corresponding to a rating of 3, and an intensity rating of 1 ( $\tan$ in color). Oxidative browning index $=2.5$. (D) Twoyear-old shoot section showing browning in approximately $30 \%$ of the xylem, corresponding to a rating of 3 , and an intensity rating of 2.5 (a mix of tan and brown). Oxidative browning index of 4.0. (E) Two-year-old shoot section showing browning in approximately $80 \%$ of the xylem, corresponding to a rating of 8, and an intensity rating of 3 (brown). Oxidative browning index of 7.0. (F) One-year-old shoot section showing browning in $100 \%$ of the xylem, corresponding to a rating of 10 , and an intensity rating of 4 (dark brown). Oxidative browning index of 9.0. Both the phloem and cambium also show severe browning. 

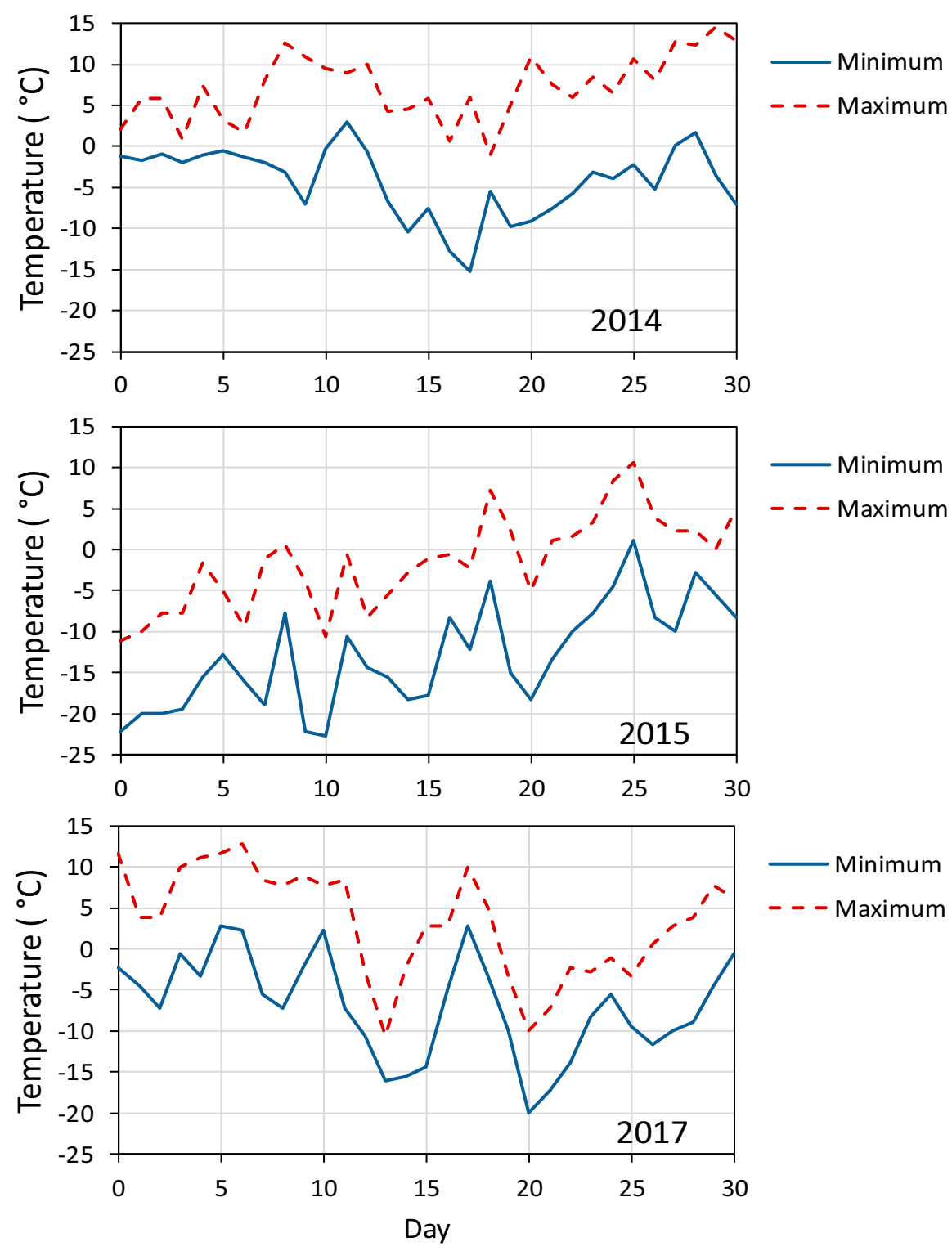

Supplemental Fig. 2. Minimum and maximum air temperature in the $30 \mathrm{~d}$ before deacclimation treatments with day 30 being the sampling date for that year. Data obtained from the National Oceanic and Atmospheric Administration (NOAA) weather station in Augusta, ME.

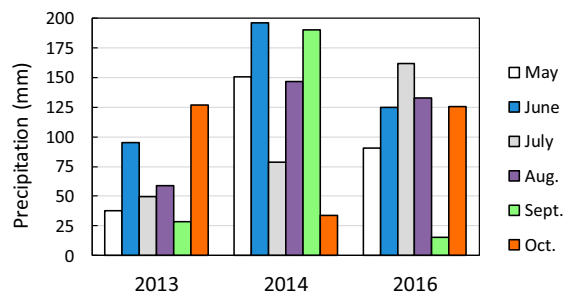

Supplemental Fig. 3. Monthly (May through October) precipitation in the growing season before deacclimation treatments. Data obtained from the NOAA weather station in Augusta, ME. 